\title{
The Effect of Levels of Gondila Date Fruit on Quality of Carbonated Gassy Beverages
}

\author{
Zeinab Osman Onsa. ${ }^{1}$, Kamal Awad Abdel Razig ${ }^{2}$ \\ HUMAN NUTRITIONST, Department of Food Science and Technology, Faculty of Agriculture \\ Al-Zaeim Al-Azhari University, P.O. Box 1432, Khartoum North, 13311, Sudan
}

\begin{abstract}
The effect of levels of Gondila honey fruit on quality of gassy beverages was investigated. Different concentrations of date honey was used $(5,10,15 a n d 20 \%)$ physical and chemical properties of the gassy beverage were analyzed. The Moisture content decreased with the increasing level of Gondeila honey, $(P \leq 0.05)$ that is the moisture content in $20 \%$ concentration was85.9\% while it is higher $(92.86 \%)$ in Gondila honey beverages $5 \%$.The protein content ( $1.75 \%)$ fat $(0.21 \%)$,fiber( 0.13$)$ carbohydrate( $10.2 \%)$ ash( 0.21$)$ and $P H$ value $(0.24 \%)$ were high $(P \leq 0.05)$ in Gondila honey beverages $20 \%$ concentration. The most abundant mineral is potassium (691.10 mg/l), calcium (6.52 $\mathrm{mg} / \mathrm{l}), \mathrm{Mg}(84.30 \mathrm{mg} / \mathrm{l})$, sodium $(54.8 \mathrm{mg} / 1)$ and iron $(0.13 \mathrm{mg} / \mathrm{l}) \mathrm{was}$ high $(p \leq 0.05)$ in $20 \%$ concentration Gondila honey beverage. Sensory evaluation cleared that15\% concentration Gondila honey beverages is the best $(P \leq 0.05)$ for appearance, texture, flavour and general acceptance, storage for 15 days is the best for all the concentration of the Gondila honey beverages.
\end{abstract}

Keywords: Gassy beverages, Date fruits Gondila honey, Chemical composition, Sensory evaluation.

\section{Introduction}

Date palm (Phoenix dactylifera L.) is one of the most important tree crops in desert areas of Northern Africa, Southern Asia and the Middle East (Hodel and Pittenger,( 2003). It is a multipurpose tree that provides food, materials for shelter, fuel and timber products in a harsh environment, where only few plants can grow Zaid(,1999). Date palm fruit is a good source of carbohydrates, fiber, minerals and vitamins, as well as having anti-mutagenic and anti-carcinogenic properties (Al-Farsi et al.,( 2005); Vayalill,( 2002). Date palm has varied medicinal uses. For example, the fruit is a good astringent remedy for intestinal problems. Syrups and pastes produced from date palm fruits are administered against colds, sore throat and bronchial cough, as well as to help relieve fever and abdominal aches; the roots are used for treating toothache Al-Shahib and Marshall,( 2003).

The date palm fruit has been used as food in most of the hot arid and semiarid regions of the world, It is one of the major food crops in Sudan, thus a large number of cultivars are growing in this semi desert region of the country, many types were grown in the northern of Sudan. Date fruits are well known as stable nutritious food and source of wealth for many years (Khan et al., 2008) date fruit is concerned in modern culture for their pleasant flavour, odour and their biting texture, in addition to their use for flavouring, food beverages and medication Vayalil,( 2002). Most of the ancient Arab depends on date fruit on daily life because of its high nutritional value, great yields and its long life, the date palm has been mention as the "tree of life" Ahmed and Ahmed, (1995). Dates considered as major source of carbohydrate's which include simple sugars like glucose, fructose and sucrose (Ahmed and Ahmed, (1995); Myhrra et al., (1999). They are good source of dietary fiber, which prevent the low density lipo-protein (LDL) cholesterol absorption in the gut, additionally the fiber works as a bulk laxative, thus help to protect the colon mucous membrane, from cancer causing chemical binding to it in the colon. They are good sources of dietary minerals, like iron potassium, selenium and calcium. And vitamin A, B1, B2 and niacin, but low in fat, protein content (Sawaya et al., 1983; Myhrra et al.,( 1999).The objective of this study is to study the effect of using different concentration of (Gondila) honey, (5-10-15-20\%) on the quality of gassy beverages.

\section{Materials and Method}

Date fruit of cultivar (Gondila) was brought from the local market in (Omdurman) Khartoum state Sudan. Soda water which contains 85\% carbon dioxide was brought from (Arak company) Khartoum north Khartoum state Sudan. Sugar, sucrose, Kenana product, used as $10 \%$ per 100 gm. acid $1 \%$ (lemon juice fresh), and Arabic gum for fixation 1\%.

Preparation of Gondila honey, by weighing 1265 gm. of Gondila, added to boiled water $2200 \mathrm{ml}$ for 15 minutes and cooked in a pressure cooker then thieved wisely and put in a direct heat without cover, after the evaporation, the honey was concentrated and put in a container after being cold. The carbonated beverages is made of 500 gm honey $+50 \mathrm{gm}$ lemon juice $+50 \mathrm{gm}$ Arabic gum +1050 soda water, and divided to 3 parts, each $350 \mathrm{ml}$ and put in a container.

Physicochemical properties of date gassy beverages Moisture, protein, fat, fiber, carbohydrate, Ash content and titretable acidity were determined according to the method of AOAC (1990). The $\mathrm{pH}$ by using the method described by Newlander and Ahtertion (1964), the mineral determination by the spectrophotometer according to the method of Perkin Elmer (1994).Ascorbic acid determined according to AOAC (1980).

Sensory evaluation was done by the scoring method according to the method of Ihekronye and Ngoddy,( 1985) and the statistical analysis was done by (Mead and Currnow,( 1983). 


\section{International Journal of Science and Research (IJSR) \\ ISSN (Online): 2319-7064 \\ Index Copernicus Value (2013): 6.14 | Impact Factor (2015): 6.391}

\section{Result and Discussion}

Physicochemical properties of date gassy beverages Moisture content decreased with the increasing level of Gondila honey that is the moisture content of $20 \%$ concentration was $85.94 \%$ while the concentration of $5 \%$ Gondila honey was high in moisture content $92.86 \%$ at the same time the other concentrations $(10-15 \%)$ is in the middle $(90.90 \%, 88.15 \%)$. The differences could be due to the concentration and the time given for evaporation (Table.1).the result obtained in this study was in agreement with Khatab et al., (1982) who reported that the moisture content of Gondeila was70-90\% .

The protein content in the gassy beverages, the $20 \%$ concentration is the highest of all $(1.75 \%)(\mathrm{P} \leq 0.05)$ while the $5 \%$ concentration is the lowest in protein, these result is in agreement with earlier report of (Khattab et al., 1982; Nour and Magboul 1982),it is also in accordance with that obtained by (Alhotti et al., 1995and Takroni, 2005).

The gassy beverages, the one of $20 \%$ concentration of honey is high $(\mathrm{P} \leq 0.05)$ in Ash $0.21 \%$ while the $5 \%$ concentration is the least 0.03 .The result obtained was in agreement with that reported by Khattab et, al.,(1983) than that reported by khattab et, al., (1982).and lower than that reported by Al-hotti ( ,1997).who reported that dates were not considered as a good source of protein.

The fat content of the carbonated beverages, 20\% concentration is high $(\mathrm{P} \leq 0.05)$ which is $(1.02 \%)$, and the other concentration $(15 \% .10 \%)$ is in the middle $(0.94 \%$, $0.88 \%$ ) respectively and the one of $5 \%$ concentration is 0 . $72 \%$ (table.1). Fat content in this study was higher than those reported by Al-hotti (1983). However these values were similar to those reported by Sawaya et al., (1983) for dates grown in Saudia Arabia and those reported by (Ahmed and Ahmed, 1995) for dates grown in the United Arab of Emirates, on the other hand values were lower than those reported for some Iranian varieties (Ejlali et al., 1975) also it is in accordance with Takroni,(2005). The lowest level of the fat content in the gassy beverages compared with its high content of sugars means that consumption of date beverage is safe for those suffering from heart diseases.

Carbohydrate content in the gassy beverages is high $(\mathrm{P} \leq$ 0.05 ) in the $20 \%$ concentration of honey $10.22 \%$ while the least, carbohydrate content is in the $5 \%$ concentration, 1.71 $\%$. Variation in the carbohydrate concentration of date fruit can be attributed to differences in cultivar, harvest, post- harvest factors and growing environments of date fruit (FAO, 1989).

Fiber content is high $(\mathrm{P} \leq 0.05)$ in Gondila $20 \%$ concentration $(0.13 \%)$ while it is $(0.01 \%)$ in the $5 \%$ Gondela honey. Generally date fruit can be considered as agood source of dietary fiber such as cellulose, hemicellulose, leginin, pectin(Habib and Irahim( 2011).the result obtained was significantly lower than those reported by Al-Shahib and Marshal( 2003 ) Who found that the percentage of total dietary fiber was in the range of $6.4-11.5 \%$.

The PH in the $20 \%$ concentration is the highest $(\mathrm{P} \leq 0.05)$ of all the other concentration $(4.20 \%)$ while it is $(3.90,4.00$, $3.80)$ respectively in the other concentration $(15,10.5 \%)$ (table.1). the result of $4.20 \%$ is in agreement of Abdelrahim et, al.,(2003).

Ascorbic acid content the content of the gassy beverages showed that it is high $(\mathrm{P} \leq 0.05)$ in $20 \%$ concentration honey $(0.34 \%)$ and the least is in $5 \%$ concentration $(0.17 \%)$. (table.2). the result was higher than what reported by khattab et, al.,(1983) and Takroni(2005)

\section{Minerals contents of date gassy beverages}

The minerals content of the gassy beverages showed that potassium, magnesium, calcium, sodium and iron (691.1, $84.39,6.52,0.13 \mathrm{mg} / 100 \mathrm{~g}$ ) were the highest in $20 \%$ honey while in other concentration $(5,10,15 \%)$ was less (Table.2).mineral contents in these study was lower than that obtained by Khattab etal.,(1983).also the minerals obtained in the study were lower than Suleiman et al., (2012).

Sensory evaluation of date gassy beverages the gassy beverage from Gondila showed that $15 \%$ honey levels is the best $(\mathrm{P} \leq 0.05)$ for; texture, flavour, and General appearance, then come $(20,10,5 \%)$ respectively, the period of storage 15 days is the best for all (Table.3).

\section{Conclusion}

- Gassy beverages were made from Gondila in different concentration $(20,15,10,5 \%)$.

- The protein content, the $\mathrm{pH}$, was high in $20 \%$ concentration.

- Potassium, magnesium, calcium and iron were high in $20 \%$ concentration.

- $15 \%$ Gondila honey is the best for general appearance, texture, and flavor and over all acceptability.

Table 1:Effect of Gondeila honey levels on physicochemical properties (\%) of date gassy beverages.

\begin{tabular}{|l|l|l|l|l|}
\hline \multirow{2}{*}{\multicolumn{1}{c|}{ Items }} & \multicolumn{4}{|c|}{ Levels of Gondiela honey (\%) } \\
\cline { 2 - 5 } & \multicolumn{1}{|c|}{$\mathbf{5}$} & \multicolumn{1}{c|}{$\mathbf{1 0}$} & \multicolumn{1}{c|}{$\mathbf{1 5}$} & \multicolumn{1}{c|}{$\mathbf{2 0}$} \\
\hline Moisture content & $92.86^{\mathrm{a}}+0.11$ & $90.90^{\mathrm{b}}+0.15$ & $88.15^{\mathrm{c}}+0.16$ & $85.94^{\mathrm{d}}+0.18$ \\
\hline Protein content & $0.88^{\mathrm{d}}+0.07$ & $1.05^{\mathrm{c}}+0.08$ & $1.60^{\mathrm{b}}+0.09$ & $1.75^{\mathrm{a}}+0.06$ \\
\hline Fat content & $0.72^{\mathrm{d}}+0.13$ & $0.88^{\mathrm{c}}+0.15$ & $0.94^{\mathrm{b}}+0.16$ & $1.02^{\mathrm{a}}+0.14$ \\
\hline Fiber content & $0.01^{\mathrm{d}}+0.02$ & $0.06^{\mathrm{c}}+0.05$ & $0.09^{\mathrm{b}}+0.06$ & $0.13^{\mathrm{a}}+0.03$ \\
\hline Carbohydrate content & $1.71^{\mathrm{d}}+0.11$ & $4.55^{\mathrm{c}}+0.09$ & $7.80^{\mathrm{b}}+0.08$ & $10.22^{\mathrm{a}}+0.07$ \\
\hline Ash content & $0.03^{\mathrm{d}}+0.03$ & $0.11^{\mathrm{c}}+0.05$ & $0.16^{\mathrm{b}}+0.02$ & $0.21^{\mathrm{a}}+0.04$ \\
\hline pH value & $3.80^{\mathrm{d}}+0.05$ & $3.90^{\mathrm{c}}+0.06$ & $4.0 \quad+0.08$ & $4.20^{\mathrm{a}}+0.07$ \\
\hline
\end{tabular}

- Mean + SD. having different superscript letters on rows are significantly different $(\mathrm{P}<0.05)$ 


\section{International Journal of Science and Research (IJSR) \\ ISSN (Online): 2319-7064 \\ Index Copernicus Value (2013): 6.14 | Impact Factor (2015): 6.391}

Table 2: Effect of Gondeila honey levels on vitamin C and minerals content (mg/l) of date gassy beverages.

\begin{tabular}{|l|l|l|l|l|}
\hline \multirow{2}{*}{ Items } & \multicolumn{4}{|c|}{ Levels of Gondiela honey (\%) } \\
\cline { 2 - 5 } & \multicolumn{1}{|c|}{$\mathbf{5}$} & \multicolumn{1}{c|}{$\mathbf{1 0}$} & \multicolumn{1}{c|}{$\mathbf{1 5}$} & $\mathbf{2 0}$ \\
\hline Vitamin C & $0.17^{\mathrm{d}}+0.12$ & $0.24^{\mathrm{c}}+0.08$ & $0.30^{\mathrm{b}}+0.06$ & $0.34^{\mathrm{a}}+0.04$ \\
\hline Calcium & $3.78^{\mathrm{d}}+0.05$ & $4.50^{\mathrm{c}}+0.07$ & $5.60^{\mathrm{b}}+0.03$ & $6.52^{\mathrm{a}}+0.06$ \\
\hline Magnesium & $5320^{\mathrm{d}}+0.07$ & $61.40^{\mathrm{c}}+0.08$ & $75.20^{\mathrm{b}}+0.09$ & $84.30^{\mathrm{a}}+0.011$ \\
\hline Potassium & $129.60^{\mathrm{d}}+0.13$ & $310.10^{\mathrm{c}}+0.15$ & $522.30^{\mathrm{b}}+0.18$ & $691.10^{\mathrm{a}}+0.19$ \\
\hline Iron & $0.10^{\mathrm{b}}+0.02$ & $0.11^{\mathrm{b}}+0.03$ & $0.12^{\mathrm{a}}+0.06$ & $0.13^{\mathrm{a}}+0.04$ \\
\hline
\end{tabular}

- Mean + SD. having different superscript letters on rows are significantly different $(\mathrm{P}<0.05)$

Table 3: Effect of Gondeila honey levels and storage period on appearance and texture quality of date gassy beverages

\begin{tabular}{|c|c|c|c|c|c|c|c|c|}
\hline \multirow[b]{3}{*}{ Storage period (days) } & \multicolumn{4}{|c|}{ Appearance } & \multicolumn{4}{|c|}{ Texture } \\
\hline & \multicolumn{4}{|c|}{ Levels of Gondeila honey (\%) } & \multicolumn{4}{|c|}{ Levels of Gondeila honey (\%) } \\
\hline & 5 & 10 & 15 & 20 & 5 & 10 & 15 & 20 \\
\hline \multirow[t]{2}{*}{0} & $2.0^{\circ}$ & $3.0^{\mathrm{n}}$ & $3.5^{k}$ & $3.3^{L}$ & $2.5^{\mathrm{n}}$ & $3.0^{\mathrm{L}}$ & $3.6^{\text {ih }}$ & $3.5^{1}$ \\
\hline & +0.08 & +0.06 & +0.11 & +0.09 & +0.13 & +0.11 & +0.05 & +0.06 \\
\hline \multirow[t]{2}{*}{5} & $3.0^{n}$ & $3.5 \mathrm{k}$ & $3.9^{\mathrm{h}}$ & $3.7^{\mathrm{j}}$ & $2.9^{\mathrm{m}}$ & $3.1^{k}$ & $3.9^{\mathrm{g}}$ & $3.7^{\mathrm{h}}$ \\
\hline & +0.13 & +0.14 & +0.15 & +0.11 & +0.09 & +0.03 & +0.06 & +0.07 \\
\hline \multirow[t]{2}{*}{10} & $3.3^{L}$ & $3.8^{\mathrm{i}}$ & $4.3^{\mathrm{d}}$ & $4.1^{\mathrm{f}}$ & $3.1^{k}$ & $3.9^{\mathrm{g}}$ & $4.2^{\text {ef }}$ & $4.1^{\mathrm{f}}$ \\
\hline & +0.11 & +0.08 & +0.07 & +0.06 & +0.15 & +0.11 & +0.06 & +0.08 \\
\hline \multirow[t]{2}{*}{15} & $4.0^{\mathrm{g}}$ & $4.5^{\mathrm{c}}$ & $4.8^{\mathrm{a}}$ & $4.6^{\mathrm{b}}$ & $3.9^{\mathrm{g}}$ & $4.6^{\mathrm{c}}$ & $4.9^{\mathrm{a}}$ & $4.8^{\mathrm{ab}}+0.02$ \\
\hline & +0.09 & +0.03 & +0.01 & +0.02 & +0.09 & +0.03 & +0.01 & \\
\hline \multirow[t]{2}{*}{20} & $3.1^{\mathrm{m}}$ & $4.0^{g}$ & $4.5^{\mathrm{c}}$ & $4.2^{\mathrm{e}}$ & $3.3^{j}$ & $4.3^{\mathrm{e}}$ & $4.7^{b}$ & $4.5^{\mathrm{d}}$ \\
\hline & +0.08 & +0.09 & +0.04 & +0.06 & +0.08 & +0.05 & +0.03 & +0.01 \\
\hline
\end{tabular}

- Means + SD. having different superscript letters on columns and rows are significantly different $(\mathrm{P}<0.05)$.

Table 4: Effect of Gondeila honey levels and storage period on flavour and over all acceptability of date gassy beverages

\begin{tabular}{|c|c|c|c|c|c|c|c|c|}
\hline \multirow{3}{*}{ Storage period (days) } & \multicolumn{4}{|c|}{ Flavour } & \multicolumn{4}{|c|}{ Over all acceptability } \\
\hline & \multicolumn{4}{|c|}{ Levels of Gondeila honey (\%) } & \multicolumn{4}{|c|}{ Levels of Gondeila honey (\%) } \\
\hline & 5 & 10 & 15 & 20 & 5 & 10 & 15 & 20 \\
\hline 0 & $2.1^{\mathrm{m}}$ & $3.2^{j}$ & $3.7^{\mathrm{h}}$ & $3.5^{1}$ & $2.8^{\mathrm{k}}$ & $3.0^{\mathrm{g}}$ & $3.6^{\mathrm{g}}$ & $3.4^{\mathrm{h}}$ \\
\hline 5 & $\begin{array}{l}2.6^{L} \\
+0.15\end{array}$ & $\begin{array}{l}3.5^{1} \\
+0.12\end{array}$ & $\begin{array}{l}3.11 \\
3.9^{f} \\
+0.08\end{array}$ & $\begin{array}{l}3.12 \\
3.7^{\mathrm{h}} \\
+0.11\end{array}$ & $3.0^{j}$ & $3.4^{\mathrm{h}}$ & $3.9^{f}$ & $\frac{0.14}{3.7^{\mathrm{fg}}}$ \\
\hline 10 & $\begin{array}{l}3.1^{\mathrm{k}} \\
+0.12\end{array}$ & $\begin{array}{l}3.9^{f} \\
+0.11\end{array}$ & $\begin{array}{l}4.2^{\mathrm{d}} \\
+0.06\end{array}$ & $\begin{array}{l}4.0^{\mathrm{e}} \\
+0.07\end{array}$ & $\begin{array}{l}3.3^{1} \\
+0.11\end{array}$ & $\begin{array}{l}4.0^{\mathrm{e}} \\
+0.07\end{array}$ & $\begin{array}{l}4.3^{c} \\
+0.08\end{array}$ & $\begin{array}{l}4.2^{\mathrm{d}} \\
+0.06\end{array}$ \\
\hline 15 & $\begin{array}{l}3.8^{\mathrm{g}} \\
+0.06\end{array}$ & $\begin{array}{l}4.4^{\mathrm{c}} \\
+0.07\end{array}$ & $\begin{array}{l}4.9^{\mathrm{a}} \\
+0.01\end{array}$ & $\begin{array}{l}4.7^{\mathrm{b}} \\
+0.02\end{array}$ & $\begin{array}{l}3.8^{\mathrm{fg}} \\
+0.06\end{array}$ & $\begin{array}{l}4.3^{\mathrm{c}} \\
+0.05\end{array}$ & $\begin{array}{l}4.8^{\mathrm{a}} \\
+0.01\end{array}$ & $\begin{array}{l}4.5^{\mathrm{b}} \\
+0.03\end{array}$ \\
\hline 20 & $\begin{array}{l}3.1^{\mathrm{k}} \\
+0.09\end{array}$ & $\begin{array}{l}4.2^{\mathrm{d}} \\
+0.06\end{array}$ & $\begin{array}{l}4.8^{\mathrm{ab}} \\
+0.02\end{array}$ & $\begin{array}{l}4.5^{\mathrm{c}} \\
+0.03\end{array}$ & $\begin{array}{l}3.0^{j} \\
+0.08\end{array}$ & $\begin{array}{l}4.0^{\mathrm{e}} \\
+0.07\end{array}$ & $\begin{array}{l}4.5^{\mathrm{b}} \\
+0.04\end{array}$ & $\begin{array}{l}4.3^{\mathrm{C}} \\
+0.08\end{array}$ \\
\hline
\end{tabular}

- Means + SD. having different superscript letters on columns and rows are significantly different $(\mathrm{P}<0.05)$.

\section{References}

[1] Ahmed, I.A. and W.K. Ahmed, (1995). Chemical composition of date's varieties as influenced by the stage of ripening. Food Chemistry, 54: 305-309.

[2] Abdel Rhaman, N. Y; Ahamed, M.H.; Mergani, H. A. and Abdel, R. A(2003).Date packaging and. B. Sc in Food Science and Technology Department Faculty of Agriculture University of AL-Zaiem AL-Azhari Supervisor. Khartoum. Sudan.

[3] Al Hooti, S.; Jiuan, S and Qabazard, H. (1995) Studies on the physicochemical characteristic of date Fruit of five UAE Cultivars at different stages of maturity. Arabian Gulf Journal of Food Scientific Research, 13:553-569.

[4] Al Hooti, S.;. Sidhu, J. S and Qabazard, H., (1997)Chemical Composition of Seeds of Date Fruit Cultivars of United Arab Emirates," Journal of Food Science and Technology, Vol. 35, No. 1, , pp. 44-46.

[5] Al-Farsi, M.; Alasalvar, C.; Morris, A.; Barron, M.; Shahidi, F.(2005). Compositional and sensory characteristics of three native sundried date (Phoenix dactylifera L.) varieties grown in Oman. J. Agr. Food Chem., 53, 7586-7591.

[6] Al-Shahib, W. and Marshall, R.J. (2003).The fruit of the date palm: It's possible use as the best food for the future. Int. J. Food Sci. Nutri., 54, 247-259.

[7] AOAC(1990).Association of official analytical chemistry the official method of analysis $12^{\text {th }}$ analytical chemists, Washinton, D.C. USA.

[8] AOAC.(1980) Official Methods of Analysis of the AOAC, 13th Ed; Vitamin C (Ascorbic acid) -Official Final Action, Microfluorimetric method (13) 43.061 43.064. Results are expressed asmg -Ascorbic acid/kg

[9] Chowdhury, M.S.H.; Halim, A.; Mohammed, N.; Haque, F.; Koike, M.(2008). Traditional utilization of wild date palm (Phoenix sylvestris) in rural Bangladesh: an approach to sustainable biodiversity management. J. Forestry Res., 19, 245-251.

[10] Ejlali, M; Carzouni ,J. and Bodii, F. (1975).Etude Sur Les Char- acters Biochimiques Des Dates de Varites Iraniennes," Fruits Journal, Vol. 30, pp. 411-412.

[11] El Hadrami, A and Al-Khayri, J.M.(2012). Socioeconomic and traditional importance of date palm. Emir. J. Food Agric., 24, 371-385. 


\section{International Journal of Science and Research (IJSR) \\ ISSN (Online): 2319-7064 \\ Index Copernicus Value (2013): 6.14 | Impact Factor (2015): 6.391}

[12] F.A.O,(1989) Utility of tropical food: tropical beans. Food and Agricultural Organization Puplication, pp:22-26.

[13] Habib H.M., Ibrahim W.H.(2011) Nutritional quality evaluation of eighteen date pit varieties. Int. J. Food Sci. Nutr., , 60, 99-111.

[14] Hodel, D. R.; Pittenger, D.R. (2003).Studies on the establishment of date palm (Phoenix dactylylifera) offshoots. Part1. Observations on root development and leaf growth. Palms, 47, 201-205.

[15] Ihekoronye, A.I. and Ngoddy, P.O. (1985) Integrated Food Science and Technology for the Tropics. Macmillan Pub- lishers, New York, 296-301.

[16] Khan, M.N., A. Sarwar, F. Wahab and R. Haleem, 2008. Physico-chemical characterization of date varieties using multivariate analysis of plums. Food Chemistry, 81: 321-326

[17] Khattab, A.G. El-tinay, A.H. and Nour. A. A.M.(1982).The Chemical Composition of Some Date Cultivars Grawn in the Saudi Arabia. India Journal of Horticulture. 33-107.marked as such, are protected by law.

[18] Khattab, A. G. H.; Eltinay, Al-Hassa, A. H. and Nour, A. A. M. (1983). The chemical composition of some date palm cultivars grown in Sudan. Proc. Of The First Symp., On the Date Palm. Kingdom of Saudi Arabia.

[19] Mead, R and Curnaw, R.N(1983) Statistical Methods in Agriculture experiment Biolgy. Chapman and Hall .London . England.

[20] Myhera, R.M., J. Karkdas and M.S. Taylor, 1999. The composition of maturing Omani dates. Journal of Agricultural and Food Chemistry, 76: 1345-1350.

[21] Newlander, J.A. and Atherton, H.V. (1964).The Chemistry and Testing of Dairy Products, 3rd ed. (revised), Olsen Publishing Co. Milwaukee, Wisconsin. U.S.A.

[22] Nour, A.Aand Magboul,B.I.(1982) Amino acid composition of some Sudanese date cultivar. Date palm Journal 4(1), 51-53.

[23] Perkin-Elmer (1996).is a registered trademark of The Perkin-Elmer Corporation.

[24] Registered names, trademarks, etc. used in this document, even when not specifically

[25] Sawaya, W., A. Miski, J. Khalil, H. Khatchadonian and A. Mashadi, (1983). Physical and chemical characterization of the major date varieties grown in Saudi Arabia; I Morphological measyrements proximate and mineral analyses, Date Palm Journal 2: $1-25$.

[26] Suleiman, A. M.; Abd Elhafise,I.A; Abdelrahim, M.A(2012) Comparative Study on Five Sudanese Date (Phoenix dactylifera L.) Fruit Cultivars . Food and Nutrition Sciences, 2012, 3, 1245-1251

[27] Takrouni, R. A. G.(2005) Production of date paste and its utilization in bread making. Submitted To The University Of Khartoum In Partial Fulfillment Of The Requirements For The Degree Of Master Of Science (Agric).

[28] Vayalill, P.K.(2002). Antioxidant and antimutagenic properties of aqueous extract of date fruit (Phoenix dactylifera L. Arecaceae). J. Agr. Food Chem, 50, 610-617.
[29] Zaid, A. (1999).Date Palm Cultivation; FAO Plant Production and Protection, Food and Agriculture Organization; Paper No. 156; United Nations: Rome, Italy. 